\title{
TAKO RZECZE ZARATUSTRA... O JEZUSIE. NIETZSCHE WOBEC CHRZEŚCIJAŃSTWA
}

Jaromir Brejdak, Ewangelia Zaratustry, PWN, Warszawa 2014.

Filozofia Fryderyka Nietzschego w „potocznym” odbiorze kojarzy się głównie $\mathrm{z}$ hasłem mówiącym o śmierci Boga i idącym za tą konstatacją "przewartościowaniem wartości”. $W$ takim uproszczonym rozumieniu myśl filozofa wiąże się dalej z ateizmem, immoralizmem, nastawieniem antymetafizycznym, sceptycyzmem, czy nawet - cynizmem. Ciekawym jest, że tak uproszczona, zwulgaryzowana recepcja dzieła potrafi zakorzenić się w kulturowej świadomości i wpływać również na bardziej zniuansowane analizy - nawet bowiem $w$ akademickim, dużo subtelniejszym ujęciu, Nietzsche często kojarzony jest z postawą anty-chrześcijańską, z wrogością wobec chrześcijańskiej etyki, $\mathrm{z}$ anty-transcendentalizmem, a także $\mathrm{z}$ niechęcią żywioną do postaci Jezusa, będącego rzekomo dla Nietzschego antytezą nadczłowieka. Szczęśliwie jednak wielu akademików pochylających się nad dorobkiem Nietzschego dostrzega złożoność i nieoczywistość jego myśli oraz, co za tym idzie, jego skomplikowane podejście do chrześcijaństwa (tak w wymiarze historycznym, jak i teologicznym).

Myśl Nietzschego zajmowała (i wciąż zajmuje) nie tylko filozofów, lecz również historyków idei, filologów czy kulturoznawców. Dorobek niemieckiego myśliciela analizie poddawali między innymi Martin Heidegger, Gilles Deleuze, Karl Jaspers, Lew Szestow czy Paul de Man. Również na polskim gruncie mamy do czynienia z bogatym piśmiennictwem dotyczą- 
cym jego życia i twórczości, by wspomnieć chociażby prace Michała Pawła Markowskiego, Bogdana Barana, Krzysztofa Jerzego Michalskiego, Zbigniewa Kuderowicza czy Mirosława Żelaznego. Wśród licznych prac poświęconych Nietzschemu na uwagę zasługuje również najnowsza książka Jaromira Brejdaka, Ewangelia Zaratustry¹. Co wyróżnia tę pozycję spośród innych?

Sam Brejdak tak opisuje swój projekt: „Niniejsza praca ma charakter komentarza do Tako rzecze Zaratustra [...], poprzedzonego analizą dwóch tekstów: Narodzin tragedii $z$ ducha muzyki oraz O pożytkach i szkodliwości historii dla życia, tworzących pewną całość. Komentarz ten nie jest bezinteresowny, towarzyszy mu bowiem pytanie przewodnie o relację i związek «piątej ewangelii Zaratustry» $\mathrm{z}$ ewangelią Jezusa; pytanie nieustannie powracające: "Zaratustra - uczeń czy adwersarz Jezusa?»" (s. 12).

Takie postawienie problemu nie jest może ujęciem zupełnie nowatorskim, sądzić można jednak, że chociaż o podobne zestawienie pokusiło się już uprzednio wielu badaczy, to tylko nieliczne rozstrzygnięcia i analizy czynione $w$ tym obszarze były tak wnikliwe i oryginalne jak te zaproponowane w Ewangelii Zaratustry. Książka Brejdaka pod apokryficznym tytułem skrywa całkiem interesującą egzegezę zarówno pism Nietzschego, jak i Nowego Testamentu, przy czym pozostaje, o dziwo, w lwiej części swych rozstrzygnięć bliska duchowi ortodoksji.

Badacze dorobku Nietzschego dużą wagę przywiązują do jego oglądu chrześcijaństwa, wskazując na krytyczny stosunek filozofa do kwestii wiary religijnej. Jego mało pochlebny stosunek do etyki chrześcijańskiej odczytywany bywa bądź jako odrzucenie "religii słabych” na rzecz woli mocy, bądź też, w bardziej subtelnych analizach, jako krytyka tego, co chrześcijaństwo jako system religijny i społeczno-polityczny uczyniło z oryginalnym przesłaniem Nazarejczyka. Badacze skupiający się na kontekście historycznym wskazują nadto na prace Nietzschego jako na swoistą krytykę czasów, w których żył - jawi się on wówczas jako krytyk nie tyle etyki, ile kultury, która oddaliła się zbyt drastycznie od swoich źródeł. Śmierć Boga miałaby, w tej optyce, stanowić świadectwo owego niebezpiecznego oddalenia się od korzeni, czy wręcz - porzucenia własnego dziedzictwa (taki wydźwięk mają choćby analizy Alasdaira MacIntyre'a). Nawet jednak ci badacze, którzy w krytyce, jakiej Nietzsche poddaje etykę chrześcijańską, dostrzegają aspekt pozytywny, nieczęsto zauważają, że proponuje on taką własną wizję etyki, która bynajmniej nie stoi na antypodach nowotestamentowego przesłania, lecz, przeciwnie, bliska jest temu, jak filozof postrzega Dobrą Nowinę. Dostrzeżenie takich właśnie punktów wspólnych, łączących „ewangelię Zara-

\footnotetext{
${ }^{1}$ Odwołania do książki umieszczane będą bezpośrednio w tekście.
} 
tustry" z „ewangelią Jezusa”, a także wnikliwa ich analiza, stanowi z pewnością o dużej wartości książki Brejdaka.

Brejdak analizuje wybrane pisma Nietzschego, ustawiając je w porządku chronologicznym. Tym samym ukazuje, jak ewoluowały poglądy niemieckiego filozofa na kwestie twórczości i sztuki, sprzężenia estetyki z etyką, problematykę relacji transcendencji i immanencji, w końcu - na autentyczne, historyczne figury mędrców, proroków i świętych, wśród których znajduje się, rzecz jasna, również Jezus z Nazaretu. To zestawienie, którego dokonuje Nietzsche, a za nim Brejdak - zestawienie Jezusa z innymi mędrcami, filozofami czy bogami, jak Sokrates, Platon, Dionizos, Apollo, a także Mojżesz, Spinoza, a nawet Brutus (s. 39), nie jest pomysłem nowym. Podobne porównania znaleźć można przykładowo w filozofii i literaturze oświecenia ${ }^{2}$. Nienowe jest również Nietzscheańskie odczytywanie Nazarejczyka jako mistrza cnoty, wzoru etycznego, mędrca. Jak jednak celnie zauważa Brejdak, „późny Nietzsche" wychodzi poza czy ponad tego typu proste zestawienia i odczytania, wiążąc przesłanie Jezusa z własną propozycją nowej etyki, która w nowym świetle postawi całą dotychczasową jego, to jest Nietzschego, twórczość, i która wreszcie stanie się poszukiwanym przez filozofa źródłem sensu i moralności - moralności, dodajmy, przynoszącej metanoia.

Brejdak na samym początku swych rozważań kreśli zatem poszczególne etapy filozofii Nietzschego, wyróżniając kolejno między innymi: fazę metafizyki twórczości, fazę akceptacji totalnej życia, amor fati, uwielbienia życia jako twórczego procesu, i w końcu fazę woli mocy, w której niemiecki filozof uwypukla liczne niebezpieczeństwa nihilizmu. Brejdak omawia ze szczegółami jednak nie tylko poszczególne fazy twórczości Nietzschego, poddając analizie różne jego dzieła (m.in. wspomniane już Narodziny tragedii czy O pożytkach $i$ szkodliwości historii...), lecz również na poszczególne części czy etapy rozkłada "drogę Zaratustry”, szczegółowej egzegezie poddając kolejne jego nauki. Brejdak, poszukując, jak wspomniano, punktów wspólnych nauki Zaratustry i Jezusa, skupia się, jak sam pisze, na „Jezusie późnego Nietzschego" (s. 116). Dlatego też zauważa: „Zaratustra, podobnie jak Jezus, pragnie narodzin «nowego człowieka», który dokończy boski akt stworzenia. Jest on mesjaszem kosmo- i ontogenezy, mesjaszem, który nie moralizuje, lecz tworzy. Ewangelia Jezusa [...], tak jak i Zaratustry, jest ewangelią tworzenia, zdecydowanie bardziej ontologią niż nauką moralną" (s. 13). Początkowo, jak zauważa Brejdak, Nietzsche dużą rolę przypisuje proceso-

2 Por. chociażby: B. Sesboüe, Jezus Chrystus na obraz ludzi. Krótki przegląd przedstawień Jezusa na przestrzeni historii, tłum. P. Rak, Kraków 2006, zwłaszcza rozdział „Jezus - mędrzec i mistrz cnoty", s. 47-60. 
wi „uwewnętrzniania transcendencji”. Zestawiając jego myśl z filozofią Kierkegaarda, Brejdak pisze: „Różnica między Kierkegaardem a Nietzschem leży głównie w stosunku do transcendencji, której Duńczyk, pomimo przyjęcia zdwojenia mentalnej treści oraz życia jako warunku majeutycznego poznania, nie odrzuca. Nietzscheańskim odpowiednikiem tezy podmiotowość jest prawda jest jednostronne podkreślenie jednostkowości i immanencji. Immanencja jest prawdą - jest wyrazem majeutycznego charakteru poznania" (s. 35-36).

W tej idei transcendencji uwewnętrznionej widać echa indywidualizmu, który przejawiał się już w wieku XVII w licznych ruchach „independentów” czy orędowników powrotu do prawdziwych cnót ewangelicznych, przy czym wielką rolę odgrywało tu poczucie osobistej więzi z Bogiem, które przez stulecia ocierało się o ciężki grzech pychy: „Bardzo istotną rolę w dostarczaniu tej odwagi i pewności wybrania [przez Boga - przyp. M.J.] odgrywało doświadczenie nawrócenia: było ono przełomem do nowego życia w wolności. To napawało szczególnym poczuciem godności, to właśnie czyniło $\mathrm{z}$ wybranych ludzi autonomiczne jednostki, jednak stanowiło także przewartościowanie dotychczasowych wartości, bo samouznanie było postrzegane powszechnie jako grzech Lucyfera i hybris Prometeusza [podkr. M.J.]"3. Bóg nie jest już feudalnym władcą, lecz zostaje uwewnętrzniony. Immanencja zastępująca transcendencję wiąże się jednak, jak wskazuje Brejdak, nie tylko z większą autonomią podmiotu wierzącego, lecz również z projektem budowy nowej wiary i nowej kultury, która nie zdywersyfikuje doświadczenia na wewnętrzne i zewnętrzne, nie rozdzieli życia i myśli, lecz, przeciwnie, zintegruje je (s. 37-39). Zaratustra jawi się jako "prorok religii immanentnej" (s. 48), co Brejdak zestawia z Feuerbachowską wizją religii, w której teologia staje się antropologią, a Bóg jawi się jako zwierciadło człowieka. Zauważyć warto na marginesie, że Homo homini Deus Feuerbacha kojarzyć się może z nieco łagodniejszą koncepcją Homo Salvator Dei, którą w swej Sztuce ascezy4, niejako w nawiązaniu do filozofii Nietzschego ${ }^{5}$, proponuje Nikos Kazantzakis. Pisarz stwierdza: „Nie, nie Bóg nas zbawi. To my zbawimy Boga walcząc, tworząc, przetwarzając materię w ducha"6. Znawca twórczości greckiego pisarza, Ilias Wrazas, komentując

3 J. Płuciennik, Literatura, głupcze! Laboratoria nowoczesnej kultury literackiej, Kraków 2009, s. 143.

${ }^{4}$ N. Kazantzakis, Sztuka ascezy, tłum. E.T. Szyler, Warszawa 1993.

${ }^{5}$ Kazantzakis był autorem pracy doktorskiej poświęconej Nietzschemu, a myśl niemieckiego filozofa pozostawała dlań, wraz z Bergsonowską koncepcją elan vital, jedną z podstawowych inspiracji intelektualnych. Szerzej na ten temat pisze I. Wrazas w książce Zbawca Boga. Kuszenia Nikosa Kazantzakisa, Wrocław 2009.

${ }^{6}$ N. Kazantzakis, op. cit., s. 77. 
koncepcję człowieka jako Zbawcy Boga, bezbłędnie dostrzega jej Nietzscheańskie konotacje: „Samodoskonalenie się oznacza tu przekroczenie tego, co w człowieku małe, wyjście z dławiącej i dusznej atmosfery prozaiczności ku oczyszczającej atmosferze wolności. Homo Salvator Dei to ktoś mający «wolę mocy», wolę przekraczania samego siebie i doskonalenia się"7. W te Kazantzakisowskie (a także Feuerbachowskie) intuicje doskonale wpisuje się analiza Brejdaka, który w „ewangelii Zaratustry” dopatruje się wezwania do dokonania aktu samotranscendencji (s. 119). Co miałoby ową przemianę zapoczątkować? Szukając odpowiedzi na to pytanie, Brejdak powoli zmierza do konkluzji, ujawniając wspomnianą wspólnotę przekazu Zaratustry i Jezusa - początkiem samotranscendowania się człowieka jest przebaczenie, które "różni się od kary tym, że w nim człowiek, ukazany w jego pełnej egzystencji, zostaje niejako zrodzony na nowo. Przebaczenie jest obietnicą nowej pogłębionej tożsamości, wyłaniającej się dzięki perspektywie miłości i życzliwości przebaczającego. Jest więc zdominowane horyzontem przyszłości. Nie chodzi tu tylko o restytucję naruszonego, starego porządku, lecz o stworzenie porządku nowego" (s. 119). Nowy porządek Zaratustry jest przekroczeniem odruchu zemsty, która jest zbrodnią przeciw człowiekowi i przeciw życiu. Nowy porządek jest paruzją nadczłowieka. To dlatego, stwierdza Brejdak, odpowiadając na postawione na początku książki pytanie, Zaratustra jest uczniem, a nie adwersarzem Jezusa (s. 121) - Jezus głosi bowiem Nowe Przymierze i Dobrą Nowinę, odwracając starotestamentowy porządek Sądu i kary/odwetu na rzecz miłości i zbawienia, czyli właśnie przebaczenia. W „ewangelii Jezusa” zbawienie jest owocem miłości, w "ewangelii Zaratustry” zaś przebaczenie jest owocem cnoty darzącej. Brejdak oba przekazy poddaje błyskotliwej egzegezie, zauważając, że miłość i cnota darząca są w zasadzie synonimami, a tym samym antropologie obu przekazów są, w swej najgłębszej istocie, bliźniacze:

Tylko autentyczna i bezinteresowna miłość może być prawdziwym darem, miłość poza dobrem i złem, poza retoryką nagrody i kary. Ewangeliczne powiedzenie niechaj prawica nie wie, co czyni lewica, oddaje tę troskę o jej spontaniczny i bezinteresowny wymiar. Określenie cnoty darzącej najwyższą z cnót jest bardzo istotne, gdyż przyjęcie daru i obdarowywanie musi iść w parze $\mathrm{z}$ rozerwaniem immanencji, w której tkwi człowiek. Dawanie, jeśli ma być szczere, musi być uprzedzone przebaczeniem i zachowywać charakter majeutyczny, co oznacza, że dar nie może przytłaczać obdarowywanego, lecz go współtworzyć. Jeśli chcemy na podstawie etycznej praktyki Zaratustry zrekonstruować antropologię, byłaby to antropologia daru, a dokładniej rzecz nazywając - majeutyka daru z darowaniem win włącznie, której celem jest obudzenie bezkompromisowej miłości (s. 124).

${ }^{7}$ I. Wrazas, op. cit., s. 94. 
Przebaczenie czy zbawienie jest zatem nie tylko aktem moralnym, ale i ontologicznym. Brejdak wprost wskazuje na specyficzną Nietzscheańską wizję apokatastazy, przejawiającą się w jego idei wiecznego powrotu (s. 90), ściśle zespolonej z nową "moralnością immoralisty" (s. 89-95). Podobnie ontologiczny wymiar ma, jak słusznie zauważa badacz, nowotestamentowa koncepcja zbawienia czy przebaczenia grzechów. Jak zauważa Leszek Kołakowski: „[Jezus] przebaczał grzechy nie w sensie osobistym, [...] ale w takim, że je znosił, unieważniał, wymazywał z życia. [...] To coś więcej niż akt moralny i prawny - to akt ontologiczny, jeśli można tak powiedzieć, równy aktowi stworzenia ex nihilo; to unicestwienie świata takiego, jaki był przed przebaczeniem, zbrukanego i pogrążonego $\mathrm{w}$ zamęcie przez grzech [...], i odtworzenie świata w jego czystości, jest to powtórne stworzenie wszechświata" 8 . Co istotne jednak, tradycyjne egzegezy nie zrównują owej mocy przebaczenia z totalnym zanegowaniem Sądu, z odrzuceniem głęboko zakorzenionej w kulturze judeochrześcijańskiej koncepcji zmazy, przetworzonej w koncepcję winy ${ }^{9}$, w końcu - z unieważnieniem biblijnej ekonomii nagrody i kary. Tego Nietzsche zdaje się nie zauważać, czy też raczej - uznaje wszelkie te pozostałości po starotestamentowej „Boskiej buchalterii” za sprzeniewierzenie się idei Wcielenia i niezrozumienie istoty Dobrej Nowiny. Podobną optykę zdaje się przyjmować Brejdak, który skupia się, jak wspomniano, na punktach wspólnych nauk Zaratustry i Jezusa, nie uwypuklając nadmiernie istotnych różnic, które przecież między oboma przekazami zachodzą.

Dla Nietzschego Jezus jest postacią drugoplanową, i jako taka właśnie drugoplanowa postać występuje Nazarejczyk również w pracy Brejdaka. Jego życiu i nauczaniu nie poświęca badacz zbyt wiele miejsca, a rekonstrukcje ewangelicznych przekazów opiera właściwie na jednym tylko opracowaniu - Chrystusie autorstwa belgijskiego teologa Adolphe'a Geschégo. Zabieg ten może na pierwszy rzut oka stanowić o pewnej słabości książki Brejdaka, trzeba jednak uznać go za w dużym stopniu uzasadniony - autor rozważania swoje poświęca wszak przede wszystkim dorobkowi Nietzschego, a główny cel pracy, odpowiedź na pytanie o ewentualną wspólnotę przekazu Zaratustry i Jezusa, zostaje z powodzeniem zrealizowany bez wchodzenia w dogłębne studia nad Nowym Testamentem. Dodać przy tym należy, że przeprowadzenie takich szczegółowych oględzin życia i nauk Jezusa, a dalej - licznych ich odczytań i interpretacji, to zadanie niemożliwe

${ }^{8}$ L. Kołakowski, Jezus ośmieszony. Esej apologetyczny i sceptyczny, tłum. D. Zańko, Kraków 2014, s. 13-14.

${ }_{9}$ Por. P. Ricouer, Symbolika zła, tłum. S. Cichowicz, M. Ochab, Warszawa 1986. 
do wykonania, stąd też każda taka próba byłaby w jakimś stopniu niesatysfakcjonująca. I choć, jak wskazano, Brejdak nie uwypukla znaczących różnic między „ewangelią Zaratustry” a „ewangelią Jezusa”, to jednak cel swój z powodzeniem realizuje - odpowiada bowiem na postawione na początku pytanie o to, czy Zaratustrę odczytywać należy jako adwersarza, czy raczej ucznia Zbawiciela. Oczywistym jest, że dodatkowe wskazanie wspomnianych różnic w obu tradycjach znacząco wzbogaciłoby książkę, nie wniosłoby jednak chyba wiele nowego do głównej jej problematyki - w optyce Brejdaka bowiem podobieństwa znajdują się na głębokim poziomie i są prawdziwie znaczące, różnice zaś pozostawić można w obszarze specjalistycznych teologicznych spekulacji. Oczywiście, wskazać można na zasadniczą niezgodność Nietzscheańskiej koncepcji Wcielenia z koncepcją chrześcijańską, która to niezgodność bynajmniej nie może zostać zepchnięta w obszar mało istotnych, specjalistycznych dywagacji teologicznych, czy jednak podważałoby to dotychczasowe ustalenia Brejdaka i niwelowało uwypuklane przezeń podobieństwa? Można w to wątpić.

Wybór książki Geschégo jako głównego klucza do odczytywania postaci Jezusa nie wydaje się przypadkowy. Uznać można chyba, że to ograniczenie się do jednego tylko źródła "chrystologicznego" jest głęboko uzasadnione, jeśli wziąć pod uwagę główne cele i założenia pracy Brejdaka oraz konstrukcję i przekaz książki Geschégo. Po pierwsze, belgijski teolog rekonstruuje chrystologię jako antropologię, co ułatwia zestawienie nauk Zaratustry, w których centrum stoi człowiek, z naukami Jezusa. Brejdak pisze o „odwróconej kenozie” i nowym Wcieleniu: „Nietzscheańska koncepcja nadczłowieka może być odczytywana jako koncepcja Boga wcielonego" (s. 49), analizuje Nietzscheański projekt „nowej antropologii”, nawiązuje też, jak wspomniano, do idei Feuerbacha, który Boga postrzega jako „księgę pamiątkową najwyższych uczuć i myśli człowieka"10. Gesché pisze natomiast: „Jeśli Chrystus przyszedł, aby głosić Boga, przyszedł również po to, aby głosić człowieka. Wyraźnie mówię: «głosić», gdyż chodzi o pewien szczególny sposób mówienia o człowieku. Nie o definiowanie go (filozofia), opisywanie (socjologia) czy rozumienie (psychologia), ale raczej o «prorokowanie» o człowieku. Antropologia chrystologiczna widzi Boga jako proroctwo o człowieku"11. Belgijski teolog uchyla również „egzegetyczną furtkę", którą Brejdak następnie śmiało przekracza, by „opowiadać Jezusa” w taki sposób, w jaki opowiadać go próbował Nietzsche. Gesché podkreśla bowiem, że „Jezus domaga się, by Go opowiadano i by Go opowiadano Jemu same-

${ }^{10}$ L. Feuerbach, O istocie chrześcijaństwa, [cyt. za:] J. Brejdak, op. cit., s. 49.

11 A. Gesché, Chrystus, tłum. A. Kuryś, Poznań 2005, s. 41. 
$\mathrm{mu}^{\prime \prime} 12$, i analizuje szczegółowo ideę tożsamości narracyjnej, którą zapożycza od Paula Ricoeura. Wspomniana tożsamość narracyjna jest dla teologa mostem między Jezusem historii a Chrystusem wiary i służy procesowi tak zwanej „ewangelizacji oddolnej” - od Nazarejczyka-człowieka łatwiej dojść do idei Syna Bożego, niż od razu rzucać się na głęboką wodę teologicznej abstrakcji i spekulacji. Jezus-człowiek jest po prostu bliższy przeciętnej jednostce niż niedosięgły, nieodgadniony Absolut. Gesché pokazuje, w jaki sposób Jezus, za sprawą Dobrej Nowiny, przekroczyć może ekonomię nagrody i kary, a tym samym, głosząc nauki o miłości i przebaczeniu, pozostać blisko człowieka. Te same intuicje wykazuje Nietzsche, na co, jak wskazano, Brejdak zwraca baczną uwagę.

Jezus pozostaje zatem nieustannie otwarty na interpretację. Co więcej interpretacja jest nie tylko możliwa, ale i konieczna. Każdy tekst Objawienia musi być poddany egzegezie. Egzegeza, której dokonuje Nietzsche, może być postrzegana jako obrazoburcza, niekoniecznie jednak jako nieuprawniona. Jak pisze Ricoeur, każda interpretacja Objawienia, które jest przecież poczytywane za uniwersalne i nienaruszalne, zrelatywizowana jest do czasu, miejsca i wspólnoty, czyli warunków kulturowych, w jakich się tej interpretacji dokonuje. Gdy warunki się zmieniają, zmienia się i ortodoksja, dotychczasowe interpretacje są reinterpretowane. Proces ten, jak zauważa francuski hermeneuta, zapoczątkowany został już w samym Piśmie Świętym, gdzie nastąpiło uzupełnienie czy reinterpretacja wcześniejszych przekazów: Pierwszy Testament nie został przez Drugi unieważniony, tylko zreinterpretowany i w tym sensie "wypełniony»"13. To jednak dopiero początek wspomnianego procesu:

[...] egzegetyczna część przedsięwzięcia toruje drogę pracy interpretacyjnej na dwa sposoby: najpierw po zrekonstruowaniu tła najstarszego tekstu ustępuje on miejsca ponownemu odczytaniu, dokonanemu przez "młodszą wersję", znajdującą się w Nowym Testamencie albo Midraszu. W ten sposób zostaje wydobyta na światło dialektyka retrospekcji i wybiegania wprzód, dziejąca się w "Jednym i Drugim Testamencie". Ponadto egzegeza typologiczna, zaszczepiona na metodzie historyczno-krytycznej, otwiera drogę refleksji filozoficznej, która wykracza poza granice Kanonu i łączy sięze współczesnymi, filozoficznymi i niefilozoficznymi formami myśli [podkr. M.J.] ${ }^{14}$.

\footnotetext{
12 Ibidem, s. 95.

13 P. Ricoeur, A. LaCocque, Myśleć biblijnie, tłum. E. Mukoid, M. Tarnowska, Kraków 2003,

14 Ibidem, s. 15.
} s. 10. 
Widać zatem wyraźnie tę wspomnianą otwartość na interpretacje - nie tylko teologiczne, ale i filozoficzne. W kontekście powyższych rozważań zrozumiałym jest też, dlaczego wybranie Geschégo, inspirującego się Ricoeurem, na przewodnika po życiu i nauce Jezusa, jest tak doskonałym zabiegiem ze strony Brejdaka.

Badacz podkreśla fakt, iż Nietzsche odczytywał życie i słowa Jezusa jako odejście od ówczesnego horyzontu religijnego. Podobnie widzi tę kwestię choćby Peter Sloterdijk (ten sam, który „piątej ewangelii” poświęca całą książkę ${ }^{15}$ ), gdy pisze: „Wprawdzie Bóg głoszony przez Pawła i pozostałych apostołów zachowuje pewną liczbę cech wiążących go z żydowskim poprzednikiem, ale wskutek subwersywnie nowych chrystologicznych akcentów jego wizerunek nabiera zupełnie nieoczekiwanych, a nawet prowokujących i skandalicznych rysów"16. W optyce Brejdaka podstawą tego rozróżnienia, podstawą Nowego Przymierza, jest odejście od moralności instrumentalnej, od ekonomii nagrody i kary, w stronę cnoty darzącej, miłości i przebaczenia, które uwznioślają człowieka. Na tym jednak Brejdak nie poprzestaje, wskazując punkty, w których Nietzscheańska koncepcja Boga jawi się jako zbyt radykalna - badacz pokazuje, w jaki sposób „ocalić" można Boga, nie pomniejszając człowieka. W tym celu znowuż przywołuje koncepcję teologii czy chrystologii jako antropologii i - odwołując się tak do Geschégo, jak i Feuerbacha - pisze między innymi: „Paradygmat judeochrześcijański jest paradygmatem stworzenia, jest paradygmatem woli, a nie konieczności i przypadku. Wolność i twórczość przeciw konieczności i przypadkowi. Wolność wpisana jest tu w naturę bytu, nie jest wolnością wbrew Bogom (Prometeusz) i ponad naturą [...]. Bóg, stwarzając człowieka stwórcą, powierza mu dalszą twórczość i przemianę świata, po czym wycofuje się [...]. Jest to jedyny horyzont, w który wpisany jest człowiek i który tylko tak może «ograniczać». Że nie jest to ograniczenie poważne, zagrażające człowiekowi, wbrew obawom Nietzschego, świadczy fakt istnienia ateizmu [...]" (s. 135-136). Brejdak bardzo przytomnie wyłuskuje "pomyłki” czy, lepiej, "zbyt daleko idące interpretacje" przesłania Starego i Nowego Testamentu, jakich dokonuje Nietzsche, skupia się jednak, jak wskazano, na odnajdywaniu głębokich podobieństw między przesłaniem Zaratustry i Jezusa. Dlatego w końcowym fragmencie książki stwierdza ostatecznie: "Zaratustra z pozornego adwersarza Jezusa stał się w naszej ocenie jednym z Jego najbardziej zdolnych uczniów i następców" (s. 138).

15 Por. P. Sloterdijk, O ulepszaniu dobrej nowiny. Piata „ewangelia" Nietzschego, tłum. T. Słowiński, Wrocław 2010.

16 P. Sloterdijk, Gorliwość Boga. O walce trzech monoteizmów, tłum. B. Baran, Warszawa 2013, s. 47. 
Książka Brejdaka jest interesującą pozycją nie tylko dla osób zainteresowanych myślą Fryderyka Nietzschego, nie tylko dla wielbicieli filozofii jako takiej, ale i dla tych, których ciekawi kulturowa (w tym filozoficzna) recepcja przekazów religijnych. Brejdak odwołuje się nie tylko do Kierkegaarda, Heideggera, Schelera, Lévinasa czy Feuerbacha, ale i do Tischnera, Ratzingera, Mistrza Eckharta czy Jana od Krzyża. Interesują go nie tylko zagadnienia związane ściśle z wymienionymi tu już pismami Nietzschego, ale i problematyka granic interpretacji. Projekt Nietzschego zastanawia badacza nie tylko jako koncepcja etyczna, ale i ontologiczna, a "przewartościowanie wartości" wpisane zostaje w szerszy kontekst kulturowy.

Ciekawym zabiegiem, o którym warto na koniec wspomnieć, jest wzbogacenie książki o ilustracje i krótkie formy poetyckie autorstwa Teresy Babińskiej. Brejdak we wstępnych partiach pracy pisze o tym pomyśle następująco: "Zamysłem wprowadzenia dodatkowej narracji, narracji rysunku, jest przesunięcie środka ciężkości z elementu sokratejskiego racjonalnej analizy w stronę elementu apolińskiego, pośredniczącego między dionizyjską «otchłanią bytu» a jej chwilowym zatrzymaniem - w słowie, w pojęciu" (s. 13). Badacz nawiązuje do Nietzschego krytyki ",sokratejskiego przewrotu", czyli odejścia od tragicznego patosu i zaburzenia presokratejskiej równowagi między tworzeniem i niszczeniem. „Człowiek nauki” i „wróg sztuki" - oto, upraszczając, Sokrates w oczach niemieckiego filozofa (s. 19). Brejdak, wkraczając w obszar "sokratejskiego dyskursu", podtrzymuje, za sprawą swoistego dwugłosu z Babińską, równowagę między nauką a sztuką, pozwalając graficznej i językowej metaforze uzupełniać czy wzbogacać prowadzone przezeń analizy. Badacz pozostaje tym samym dłużnikiem tradycji zagadki czy tajemnicy, którą za Nietzschem tak szczegółowo analizował wydawca dzieł niemieckiego myśliciela, Giorgio Colli, w swych Narodzinach filozofii ${ }^{17}$. Element apolliński pozwala zatem Brejdakowi przekroczyć „sokratejskie ograniczenia". To zabieg niesłychanie ciekawy i oryginalny. Dodać należy, że wspomniane ilustracje graficzne i poetyckie nie są jedynie ozdobnikami na marginesie tekstu właściwego, nawiązania do nich znajdują się bowiem w samym korpusie głównym książki, a prowadzone przez auto-

17 Por. G. Colli, Narodziny filozofii, tłum. S. Kasprzysiak, Kraków 1991: „Oznaką przejścia od sfery boskiej do sfery ludzkiej jest niejasność wieszczenia, to znaczy sytuacja, w której okazuje się, że słowo jest zagadkowe, a więc że ujawnia swoje pochodzenie ze świata nieznanego. Ta dwuznaczność słowa stanowi wyraz metafizycznego rozdarcia, wykazuje niejednorodność boskiej mądrości i jej wyrazu, jakim są słowa” (s. 48). „Zagadce przypisywano [...] w cywilizacji archaicznej Grecji wielkie znaczenie, zwłaszcza że dostrzegano jej związki ze źródłami mądrości; nadano jej wobec tego wartość autonomiczną i wywodzono wprost ze sfery apollińskiej" (s. 53). 
ra analizy tego, co widzimy, uzupełniają wywód, stanowiąc integralną jego część.

Podsumowując, uznać należy, że książka Jaromira Brejdaka zasługuje na najwyższą uwagę przez wzgląd na swoją merytoryczną i formalną oryginalność. Jak wspomniano, będzie ona ciekawa nie tylko znawców myśli Nietzschego, nie tylko filozofów czy historyków idei, ale i kulturoznawców czy osób zainteresowanych relacjami między religią a nauką oraz sztuką i filozofią. Rozpoznania oferowane w omawianej pracy są wnikliwe i subtelne, a pewne konieczne uproszczenia czy skróty nie umniejszają bynajmniej jej wartości poznawczej. 